\title{
Small-Scale Patterns in the Distribution and Condition of Bamboo Coral, Keratoisis grayi, in Submarine Canyons on the Grand Banks, Newfoundland
}

\author{
Krista D. Baker ${ }^{1,2 *}$, Paul V. R. Snelgrove ${ }^{3}$, David A. Fifield ${ }^{4}$, Evan N. Edinger ${ }^{5}$, \\ Vonda E. Wareham ${ }^{1}$, Richard L. Haedrich ${ }^{2 \dagger}$ and Kent D. Gilkinson'
}

${ }^{1}$ Fisheries and Oceans Canada, Northwest Atlantic Fisheries Centre, St. John's, NL, Canada, ${ }^{2}$ Department of Biology, Memorial University of Newfoundland and Labrador, St. John's, NL, Canada, ${ }^{3}$ Department of Ocean Sciences and Biology, Memorial University of Newfoundland and Labrador, St. John's, NL, Canada, ${ }^{4}$ Environment and Climate Change Canada, Mount Pearl, NL, Canada, ${ }^{5}$ Departments of Geography, Biology, and Earth Sciences, Memorial University of Newfoundland and Labrador, St. John's, NL, Canada

OPEN ACCESS

Edited by:

Les Watling,

University of Hawai'i at Mānoa, United States

Reviewed by:

Jaime Selina Davies,

University of Plymouth,

United Kingdom

Rhian G. Waller,

University of Gothenburg, Sweden

*Correspondence:

Krista D. Baker

Krista.Baker@dfo-mpo.gc.ca

${ }^{\dagger}$ Deceased

Specialty section:

This article was submitted to Deep-Sea Environments and Ecology, a section of the journa

Frontiers in Marine Science

Received: 04 April 2019

Accepted: 17 June 2019

Published: 02 July 2019

Citation:

Baker KD, Snelgrove PVR Fifield DA, Edinger EN, Wareham VE, Haedrich RL and Gilkinson KD (2019)

Small-Scale Patterns

in the Distribution and Condition

of Bamboo Coral, Keratoisis grayi, in Submarine Canyons on the Grand

Banks, Newfoundland.

Front. Mar. Sci. 6:374.

doi: 10.3389/fmars.2019.00374
Keratoisis grayi is one of the most abundant large gorgonian corals found off Newfoundland and Labrador, yet we know little regarding the factors influencing its distribution, abundance, and condition. We employed remotely operated vehicle (ROV) transect data collected in three canyons off the Grand Banks, Newfoundland to quantitatively examine the influence of depth, bottom type, canyon, and trawling intensity on $K$. grayi abundance, height, and condition at small spatial scales. While surveying $105 \mathrm{~km}$ of seafloor with a ROV, we observed $5770 \mathrm{~K}$. grayi colonies and 167 trawl marks. We found that $K$. grayi were significantly more likely to occur in boulder areas than in cobble or gravel. Bottom depth related positively and significantly with colony height and our models predict that the largest bamboo coral colonies occur in boulders in Halibut Channel, and in boulders and cobble in Haddock Channel. The majority of colonies observed were alive and undamaged, but tipped, broken, dead and partially dead colonies were also recorded. K. grayi were more likely to occur in trawled areas, but these colonies were more likely to be damaged, broken, smaller in size, and less abundant than colonies outside trawled areas. These results demonstrate a negative impact of bottom trawling on K. grayi colonies off Newfoundland and Labrador and that fishers may specifically target areas where these corals occur.

Keywords: gorgonian coral, trawling, fishing effects, deep-sea, cold-water coral

\section{INTRODUCTION}

Deep-sea octocorals have garnered world-wide attention because of their potential longevity (Sherwood and Edinger, 2009), importance for biodiversity and life-history of other taxa (BuhlMortensen et al., 2010; Baillon et al., 2012), fragility to fishing damage (Edinger et al., 2007; Yoklavich et al., 2018), and vulnerability to other anthropogenic disturbances such as oil and gas exploration and ocean acidification (Dayton et al., 1995; Gass, 2003; Roberts and Hirshfield, 2004). Deep-sea octocoral conservation concerns underscore the growing need to better understand the factors influencing their distributions at a range of spatial scales. 
Previous studies related deep-sea octocoral distributional patterns to temperature (Bryan and Metaxas, 2006; Mortensen et al., 2006), substrate (Baker et al., 2012a), salinity (Mortensen et al., 2006), slope, oxygen (Yesson et al., 2012), and other environmental factors. For example, Paragorgiidae along the Atlantic continental margin occurred primarily between 300 and $500 \mathrm{~m}$, in areas with slopes between $1.1^{\circ}$ and $1.4^{\circ}$, temperatures $>5^{\circ} \mathrm{C}$, currents between 10 and $30 \mathrm{~cm} \mathrm{~s}^{-1}$, and low chlorophyll a concentrations (Bryan and Metaxas, 2006). Watanabe et al. (2009) reported a strong negative correlation between Primnoa resedaeformis abundance and depth and a positive correlation with cobble and/or boulders in the Northeast Channel, off Nova Scotia, Canada.

Given the known vulnerability of cold-water corals to trawling damage, distributional patterns could relate to current and past fishing intensity (Roberts et al., 2009). The majority of research related to this topic has focused on scleractinian corals. For example, an estimated $5-52 \%$ of the total area covered by Lophelia pertusa in Norwegian waters was damaged by fishing activities (Fossa et al., 2002), and researchers attributed destruction of all but $10 \%$ of Oculina spp. in a Florida reserve to illegal trawling activity (Koenig et al., 2005). However, trawl survey data, showed highest abundances of gorgonians (and deep-water corals, in general) in areas with little to no past trawling along the eastern Grand Banks and Flemish Cap (Murillo et al., 2010). Althaus et al. (2009) also reported reduced density of scleratinians, antipatharians, and alcyonaceans (combined) on trawled seamounts, compared to untrawled seamounts off Australia.

The octocoral colonies that remain in previously trawled areas may be heavily damaged. In Alaskan waters, only 31 Primnoa spp. colonies remained in a trawl path visited 7 years after the removal of $1 \mathrm{t}$ of corals; five large colonies were missing 95$99 \%$ of their branches and $80 \%$ of the polyps were missing from two smaller colonies (Krieger, 2001). Nearly 50\% of the bamboo coral colonies observed in an area subjected to heavy trawling off California and Oregon were damaged or disturbed (Yoklavich et al., 2018).

Keratoisis grayi, a long-lived bamboo coral found throughout the North Atlantic and Mediterranean Sea (Appeltans et al., 2012), is among the most common large gorgonians off Newfoundland and Labrador, Canada (Wareham and Edinger, 2007; Baker et al., 2012a). Using fisheries observer and Fisheries and Oceans Canada survey data from that region, Wareham and Edinger (2007) reported K. grayi (synonym: K. ornata: Deichmann, 1936; van der Land, 1994) in depths from 195 to $1,262 \mathrm{~m}$. Baker et al. (2012a) reported K. grayi often co-occurred with Acanthogorgia armata and Anthomastus spp. at relatively shallow depths with boulders and cobbles. $K$. grayi was associated with steep topography and semiconsolidated mudstone in a submarine canyon off Nova Scotia (Mortensen and Buhl-Mortensen, 2005). Large gorgonians (including $K$. grayi) were recorded as bycatch in multiple fisheries spanning trawl sets (Pandalus borealis, Reinhardtius hippoglossoides, and Sebastes spp. fisheries), crab pots, longlines (R. hippoglossoides and Hippoglossus hippoglossus fisheries), and gillnets ( $R$. hippoglossoides and Sebastes spp. fisheries) off
Newfoundland between 2004 and 2005 (Edinger et al., 2007), illustrating the vulnerability of $K$. grayi to fishing disturbances.

We employed remotely operated vehicle (ROV) transect data collected in three canyons off the Grand Banks to examine quantitatively the influence of depth, bottom type, canyon, and trawling intensity on K. grayi abundance, height, and condition at small spatial scales.

\section{MATERIALS AND METHODS}

\section{Video Surveys}

We explored three submarine canyons on the slopes of the Grand Banks south of Newfoundland: Halibut Channel, Haddock Channel, and Desbarres Canyon (Figure 1) with the ROV, Remotely Operated Platform for Ocean Science (ROPOS) (CSSF, 2010). The southerly flowing, cold Labrador Current and the northerly flowing, warm Gulf Stream both influence the three canyons. Fishers frequently target the areas using trawlers directed at Sebastes spp. and various flatfish, usually at depths shallower than 1000 m (Kulka and Pitcher, 2001; Edinger et al., 2007; Koen-Alonso et al., 2018). Trawl surveys in these areas indicate the presence of abundant and diverse cold-water coral taxa (Edinger et al., 2007).

Remotely Operated Platform for Ocean Science performed video surveys from CCGS Hudson during seven dives between July 16 and 24, 2007 (see Baker et al., 2012a,b, for details). The ROV was equipped with lasers placed $10 \mathrm{~cm}$ apart to indicate scale. Depth, date, time, altitude (distance above bottom), temperature, and position were logged at 1-s intervals (though sporadic problems with the logger resulted in several long periods with no temperature data).

Based on known distributions of corals in relation to bathymetry, we planned 1-km transects at 200-m depth intervals along depth contours between 2200 and $600 \mathrm{~m}$ and along contours every $100 \mathrm{~m}$ in waters shallower than $500 \mathrm{~m}$ (Baker et al., 2012a,b). We standardized transects by maintaining the $\mathrm{ROV}$ as close to the bottom as possible, at a constant slow speed (approx. 0.2-0.5 $\mathrm{m} \mathrm{s}^{-1}$ ) while tilting the camera down slightly on a wide-angle view in order to image the seafloor and water column directly above. Between pre-selected transects, we explored the area with ROPOS, capturing still images and video of interesting features, and collecting voucher specimens to validate visual identification.

\section{Video Processing}

Using the program ClassAct Mapper (Benjamin, 2007), we recorded continuous geo-referenced data describing bottom type, ROV mode, trawl marks, and corals. We identified all corals to the lowest possible taxonomic level (typically species) and measured colony height and diameter of K. grayi to the nearest $5 \mathrm{~cm}$ using the lasers for scale. Whenever possible, we quantified the general condition of colonies using two descriptors: proportion of colony dead and overall status. We estimated the proportion of each colony that appeared dead to the nearest 5\%, using the lasers for scale. The overall status of each K. grayi colony was scored as "normal" (the colony appeared 


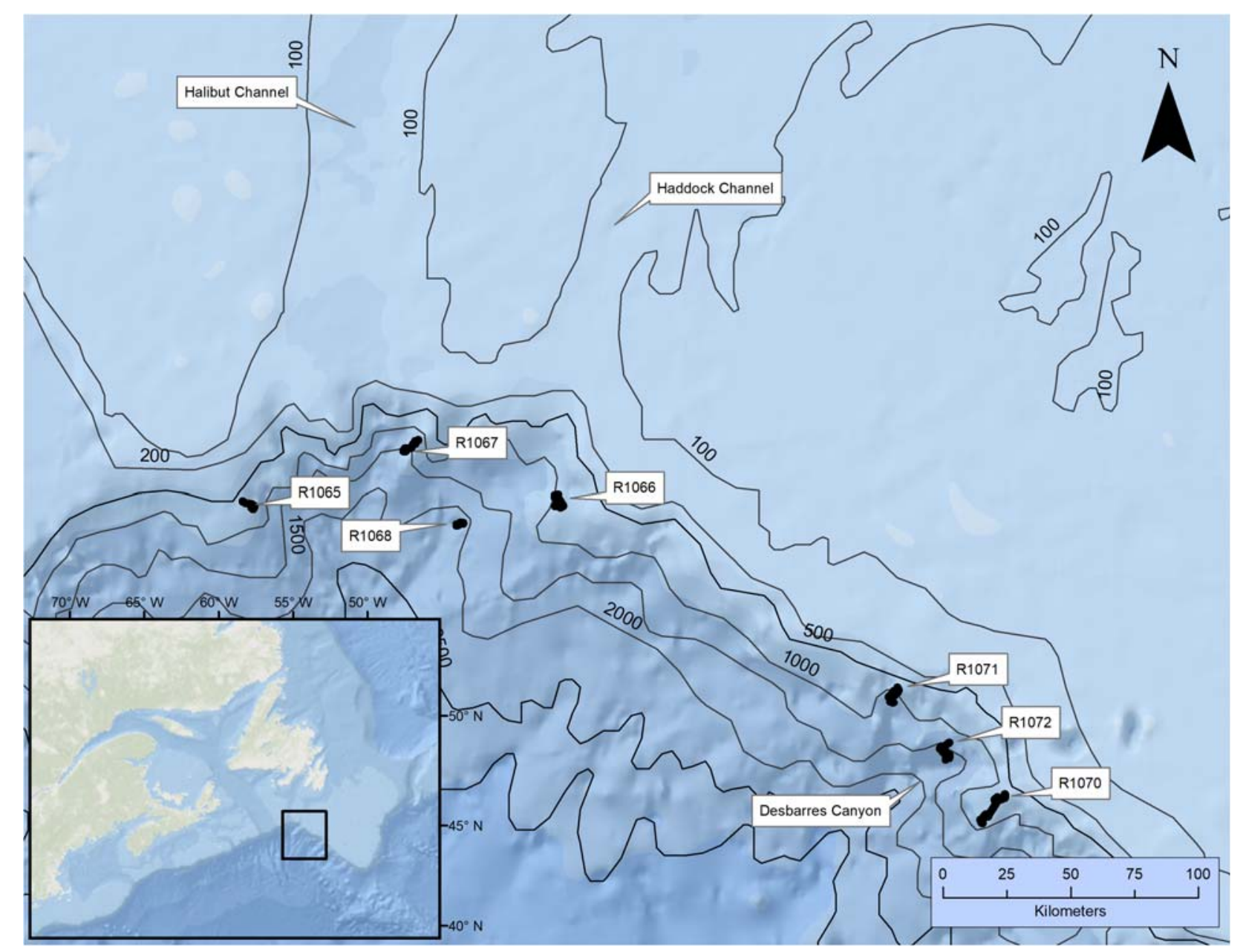

FIGURE 1 | Locations surveyed using the remotely operated vehicle, ROPOS. Individual dive numbers and canyons of interest are identified.

upright), "broken" (the colony or pieces of the colony appeared detached), or "tipped" (the colony was tilted and laying against another object, such as the substrate). If a colony was both broken and tipped, we classified it as broken.

We characterized bottom type every second by primary (most abundant) substrate and secondary (next most abundant) substrate, with optional additional comments. Bottom types included (1) outcrop (vertically exposed bedrock and consolidated Quaternary sediment), (2) boulder $(>25 \mathrm{~cm})$, (3) cobble $(5-25 \mathrm{~cm})$, (4) gravel $(0.2-5 \mathrm{~cm})$, or (5) mud-sand (fine-grain) sediments (Thrush et al., 2001).

We defined "transect-mode" as any portion of the video when the ROV followed the prescribed methodology for transects (described above), regardless of whether the transect was planned. All other ROV behaviors were combined as "Other" (Baker et al., 2012a,b).

\section{Data Analysis}

Flatfish and Sebastes spp. in the area are typically fished using bottom trawls. Commercial trawl-doors off Newfoundland spread approximately $116 \mathrm{~m}$ for flatfish trawlers and $95 \mathrm{~m}$ for Sebastes spp. trawlers. Therefore, using ArcGIS 9.3 (ESRI, 2008), we created circular $100-\mathrm{m}$ buffers around each observed trawl mark location. We then calculated the frequency with which each second of video coincided with a buffer to determine the potential trawling intensity at each second ( location).

Our analysis considered the effect of average temperature, bottom type, depth, canyon, trawl intensity (Trawl), and their interactions. However, because of strong collinearity in average temperature and depth, we removed average temperature from consideration (furthermore, $72 \%$ of the colonies had no associated temperature records). When necessary, we $\log _{10}$-transformed Trawl in our models to adjust for nonlinearity (logTrawl), and chose all final models through backward selection using likelihood ratio tests to remove insignificant terms.

\section{Abundance}

We examined patterns in K. grayi colony abundance observed when the ROV was in transect-mode by splitting transects into 10 -m segments (=sample unit) and summing the number of live 
K. grayi colonies ( $<100 \%$ dead) in each segment. Regardless of abundance, large, hard substrates likely influence $K$. grayi distribution (Baker et al., 2012a). Therefore, we used the largest size category in each 10 -m segment to classify bottom type in that segment. We used mean depth of each $10-\mathrm{m}$ segment as "depth" and maximum number of trawl mark buffers coinciding with any point in the segment as the Trawl value for that segment. Given low sample sizes, we chose to remove the $10-\mathrm{m}$ segments in mud-sand, outcrops, or depths $>1000 \mathrm{~m}$. Because the data were zero-inflated we chose a hurdle (zeroaltered) model. A hurdle model consists of two parts: a binomial generalized linear model (GLM) to model presence/absence, combined with a count model for values greater than zero (Zuur et al., 2009). Because our count data were overdispersed, we implemented a truncated negative binomial GLM count model using the Pscl package (Jackman et al., 2011) in $R$ (RDevCoreTeam., 2012).

\section{Height}

We used all video (regardless of ROV mode) to examine patterns in $K$. grayi colony height, treating each $K$. grayi colony as a sample unit. Low sample size led us to remove Desbarres Canyon and mud-sand data. A gamma GLM with identity link produced the best explanatory model for patterns in height of K. grayi.

\section{Condition}

We examined all video for patterns in K. grayi condition, again removing Desbarres Canyon and mud-sand data because of low sample size, and assessed status using two approaches: proportion dead and overall status (normal, broken, or tipped).

Values of zero $(n=5037)$ and $1(n=317)$ strongly skewed the proportion dead, and common transformations used for proportional data (e.g., arcsine and logit) therefore did not improve our ability to meet model assumptions. As a result, we categorized all colonies with any dead portions as "dead/partially dead," thereby creating a binary response variable: dead/partially dead (1) or alive (0). We used a binomial GLM to examine patterns in live versus dead/partially dead colonies, and a multinomial logit model to examine overall status (normal, broken, or tipped).

\section{RESULTS}

We surveyed approximately $105 \mathrm{~km}$ (90 h) of seafloor, and recorded a total of 5031 10-m segments using all dives and depth categories (see Baker et al., 2012a,b). We observed 5770 $K$. grayi colonies, most in Halibut Channel $(n=4341)$ and Haddock Channel $(n=1427)$, and only two colonies in Desbarres Canyon (Table 1).

We recorded 167 trawl marks (Table 2), spanning all canyons and depths from 377 to $821 \mathrm{~m}$. A total of $1086 \mathrm{~K}$. grayi colonies occurred within at least one $100-\mathrm{m}$ trawl buffer zone; the greatest number of buffers coinciding with a $K$. grayi colony was $13(n=8)$.

\section{Abundance}

Overall, we enumerated 3765 live $K$. grayi colonies while the ROV was in transect mode, 2820 of which occurred in $10-\mathrm{m}$ segments. Of the 142210 -m segments used in our model, a total of 440 segments contained $K$. grayi. The median of counts greater than zero in a $10-\mathrm{m}$ segment was 3 and the maximum of 43 occurred at $573 \mathrm{~m}$ within segments with boulders in Halibut Channel (Dive R1067).

TABLE 1 | Number of Keratoisis grayi colonies and status observed during ROV surveys off the Grand Banks, Newfoundland in 2007.

\begin{tabular}{|c|c|c|c|c|c|c|c|}
\hline Canyon & Dive & \# Observed & \# Normal & \# Broken & \# Tipped & \# Dead/Partially Dead & \# Alive \\
\hline Halibut Channel & R1065 & 192 & 154 & 19 & 9 & 19 & 150 \\
\hline Haddock Channel & $\mathrm{R} 1066$ & 1427 & 1090 & 184 & 57 & 213 & 1117 \\
\hline Halibut Channel & $\mathrm{R} 1067$ & 4149 & 3738 & 140 & 131 & 164 & 3773 \\
\hline Haddock Channel & $\mathrm{R} 1068$ & - & - & - & - & - & - \\
\hline Desbarres Canyon & $\mathrm{R} 1070$ & 2 & 1 & 1 & 0 & 1 & 1 \\
\hline Desbarres Canyon & $\mathrm{R} 1071$ & - & - & - & - & - & - \\
\hline \multirow[t]{2}{*}{ Desbarres Canyon } & $\mathrm{R} 1072$ & - & - & - & - & - & - \\
\hline & Total & 5770 & 4983 & 344 & 197 & 397 & 5041 \\
\hline
\end{tabular}

TABLE 2 | Number of trawl marks observed by depth and dive during ROV surveys off the Grand Banks, Newfoundland in 2007.

\begin{tabular}{|c|c|c|c|c|c|c|}
\hline Dive & $300-400 \mathrm{~m}$ & $400-500 \mathrm{~m}$ & $500-600 \mathrm{~m}$ & $600-700 \mathrm{~m}$ & $700-800 \mathrm{~m}$ & $800-900 \mathrm{~m}$ \\
\hline R1065 & - & - & - & 5 & 4 & 1 \\
\hline R1066 & - & 1 & 26 & 52 & - & 1 \\
\hline R1067 & - & 2 & - & - & - & - \\
\hline R1068 & - & - & - & - & - & - \\
\hline R1070 & 3 & 6 & 33 & 18 & - & - \\
\hline R1071 & 1 & 2 & 11 & 1 & - & - \\
\hline R1072 & - & - & - & - & - & - \\
\hline Total & 4 & 11 & 70 & 76 & 4 & 2 \\
\hline
\end{tabular}


Bottom type $(p<0.0001)$, Trawl $(p=0.018)$, and the interaction of Depth and Canyon $(p<0.0001)$ were significant predictors of $K$. grayi presence within a 10 -m segment (Table 3 ). K. grayi colonies were significantly more likely to be present as Trawl increased (Figure 2). The probability of $K$. grayi presence in habitats with boulders was significantly greater than in cobble $(p<0.0001)$ and gravel $(p<0.0001)$, but cobble and gravel habitats did not differ significantly from each other $(p=0.053)$.

The interaction of Depth and Bottom type was a significant predictor of $K$. grayi counts greater than zero $(p=0.004)$ (Table 3), and as trawl intensity (logTrawl) increased counts of K. grayi decreased $(p<0.0001)$. Trawling intensity appeared to have the greatest negative influence on $K$. grayi counts during the first trawl (Figure 3). Depth greatly influenced counts in habitats with cobble, which was less obvious in habitats with boulders and gravel (Figure 3).

\section{Height}

We determined height $($ median $=30 \mathrm{~cm}$ ) confidently for 4654 K. grayi colonies. The tallest colony $(215 \mathrm{~cm})$ occurred in a segment with cobble in the absence of trawling at $776 \mathrm{~m}$ in Halibut Channel.

Depth $(p<0.0001)$, logTrawl $(p<0.0001)$, and the interaction of Canyon and Bottom type $(p<0.0001)$ were significant predictors of $K$. grayi height (Table 3 ). We found a significant negative relationship between $K$. grayi colony height and $\log$ Trawl, and a significant positive relationship between height and depth. The predicted height of $K$. grayi increased by $0.07 \mathrm{~m}$ for each $1 \mathrm{~m}$ increase in depth. In Halibut Channel, the largest colonies occurred in habitats with boulders, in contrast with Haddock Channel where the largest colonies occurred in habitats with cobble and boulders (Figure 4).

\section{Condition}

Over $75 \%$ of the $K$. grayi colonies we recorded appeared healthy (Table 1).

LogTrawl $(p=0.0001)$ and the interaction of Canyon and Depth $(p<0.0001)$ were significant predictors of a $K$. grayi

TABLE 3 | Significant terms in models predicting abundance, height, and status of Keratoisis grayi colonies from ROV surveys off the Grand Banks, Newfoundland.

\begin{tabular}{llr}
\hline Response & Model terms & $\boldsymbol{p}$-value \\
\hline Abundance: presence/absence & Bottom type & $<0.0001$ \\
& Trawl & 0.0178 \\
& Depth $\times$ Canyon & $<0.0001$ \\
Abundance: counts & $\log _{10}$ Trawl & $<0.0001$ \\
& Depth $\times$ Bottom type & 0.0036 \\
Height & $\log _{10}$ Trawl & $<0.0001$ \\
& Depth & $<0.0001$ \\
Probability of having dead portions & Canyon $\times$ Bottom type & $<0.0001$ \\
& Canyon $\times$ Depth & $<0.0001$ \\
Overall status & $\log _{10}$ Trawl & 0.0001 \\
& Canyon & $<0.0001$ \\
& Depth & 0.0037 \\
& $\log _{10}$ Trawl & $<0.0001$
\end{tabular}

colony with dead portions $(n=5428)$ (Table 3). As logTrawl increased, so did the probability of recording a colony with dead portions (Figure 5). Depth strongly influenced the probability of dead portions in $K$. grayi in Haddock Channel, but not Halibut Channel. The probability of dead portions in a K. grayi colony in Haddock Channel was highest in the shallowest depths (Figure 5).

Canyon $(p<0.0001)$, Depth $(p=0.004)$, and logTrawl $(p<0.0001)$ were significant predictors of $K$. grayi overall status $(n=5513)$ (Table 3$)$. As trawl intensity increased, the probability of a healthy $K$. grayi colony decreased (Figure 6) and the probability of a broken colony increased $(p<0.0001)$ (Figure 6). We found no significant relationship between logTrawl and probability of a tipped colony $(p=0.848)$. Healthy $K$. grayi were more likely and broken coral less likely in Halibut Channel $(p<0.0001)$ compared to Haddock Channel. We found no significant difference between canyons when comparing the probability of a tipped colony $(p=0.313)$. As depth increased, the probability of a tipped $K$. grayi colony decreased $(p=0.003)$ (Figure 6). We found no significant relationship between the probability of a broken colony and depth $(p=0.155)$.

\section{DISCUSSION}

\section{Abundance}

Keratoisis grayi colonies were significantly more likely to occur in boulder areas, than cobble or gravel. This species requires hard substrate for attachment, therefore, boulders presumably create more available stable habitat for attachment than smaller substrata, such as gravel or cobble. In The Gully, off Nova Scotia, K. grayi also associate with large, hard substrate (consolidated mudstone) (Mortensen and Buhl-Mortensen, 2005), and off California and Oregon bamboo corals were only observed on rock substrate (Yoklavich et al., 2018).

We found significant interactions when modeling both presence and counts of $K$. grayi. The significant Depth $\times$ Canyon interaction in predicting counts and presence of $K$. grayi indicates a between canyon difference in $K$. grayi presence and abundance at a given depth, implying that while depth is important, other environmental factors that differ between canyons likely also influence $K$. grayi distributional patterns. Other factors that co-vary with depth may account for differences in $K$. grayi between bottom types. For example, current regime may change with depth and contribute to bottom type. Multiple environmental factors, such as current velocity, temperature, sedimentation rates, slope, and food availability that likely influence presence and abundance (but not measured in the present study) may differ between depths and/or canyons and therefore help to explain these interactions (Roberts et al., 2009; Watanabe et al., 2009). Future ROV studies could include additional methodologies and sampling (e.g., Digital Terrain Modeling, CTD samples, and planktonic samples) to examine other likely contributors to coral health and abundance. 

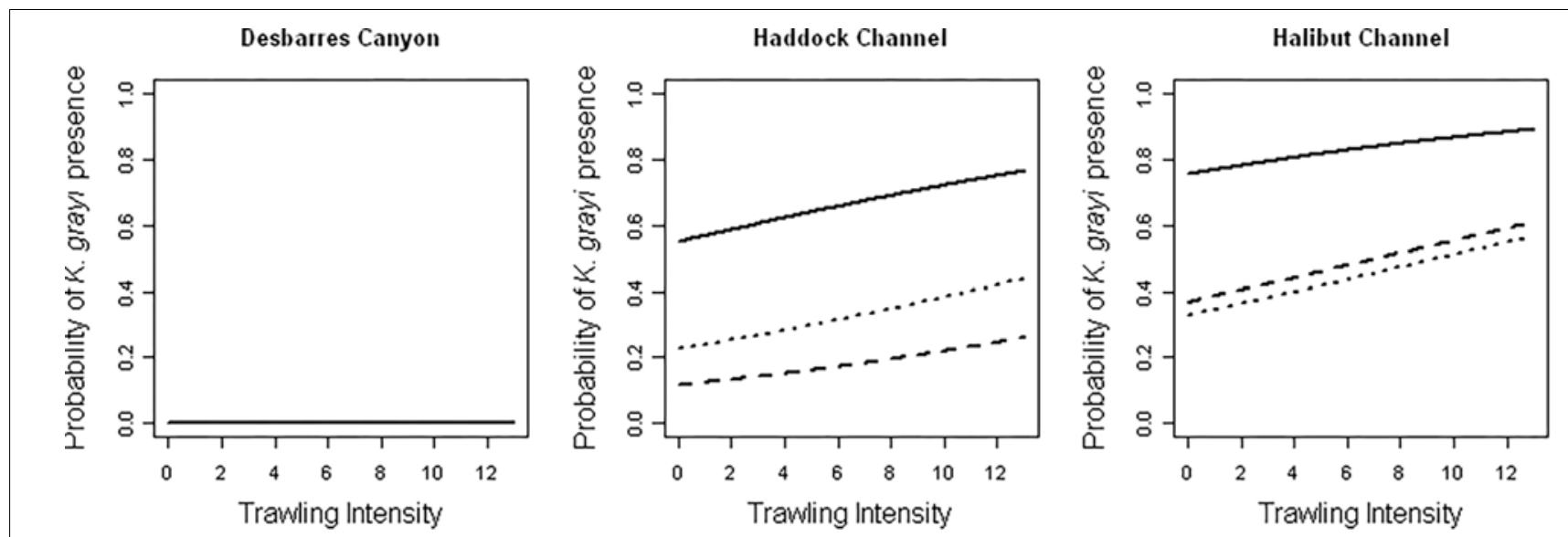

FIGURE 2 | Model predictions of the influence of trawl intensity on the probability of Keratoisis grayi presence in boulders (solid), cobble (dotted), and gravel (dashed) within each canyon. Depth was held constant at the mean depth in each canyon in all models.

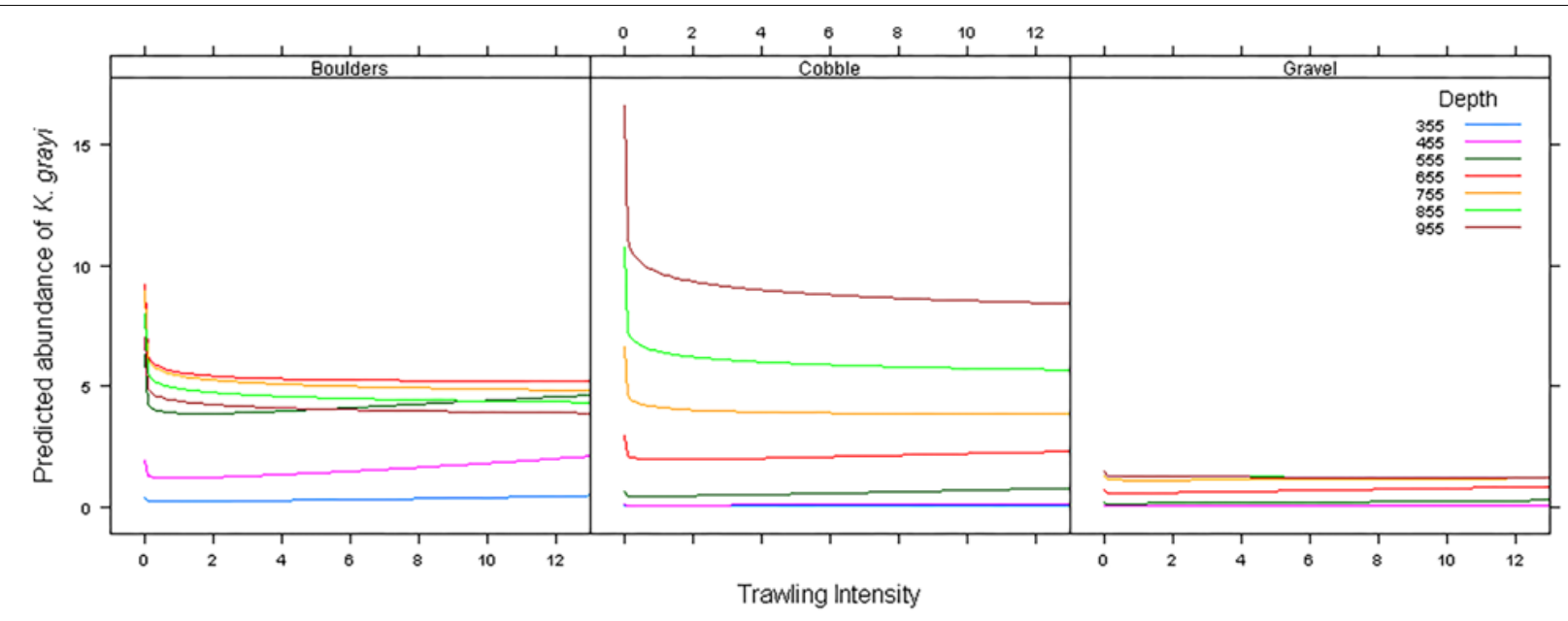

FIGURE 3 | Model predictions of the influence of trawling intensity on Keratoisis grayi counts in boulders, cobble, and gravel at various depths in Haddock Channel.
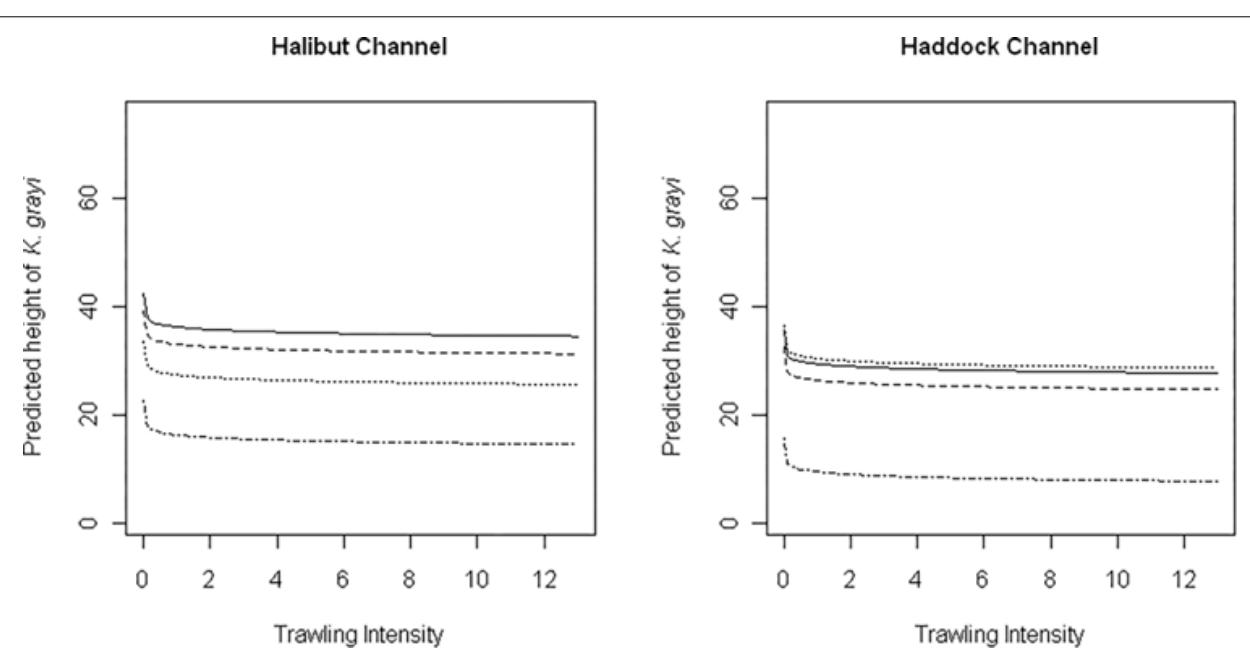

FIGURE 4 | Model predictions of the influence of trawling intensity on Keratoisis grayi height in Halibut and Haddock Channels in boulders (solid), cobble (dotted), gravel (dashed), and outcrops (dot/dash) at mean depth (650 m). 


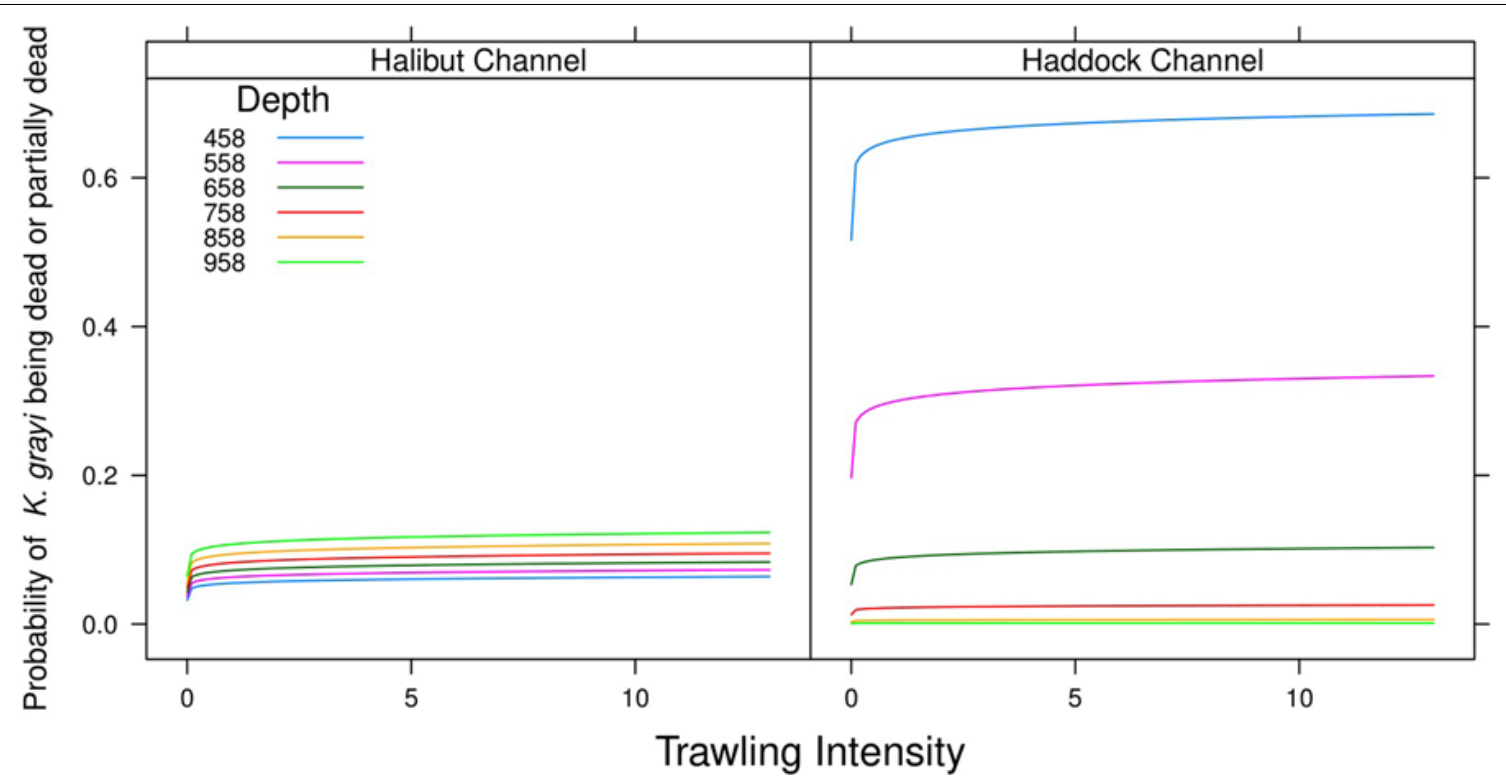

FIGURE 5 | Model predictions of the influence of trawling intensity and depth on the probability of dead/partially dead versus live Keratoisis grayi in Halibut Channel and Haddock Channel.
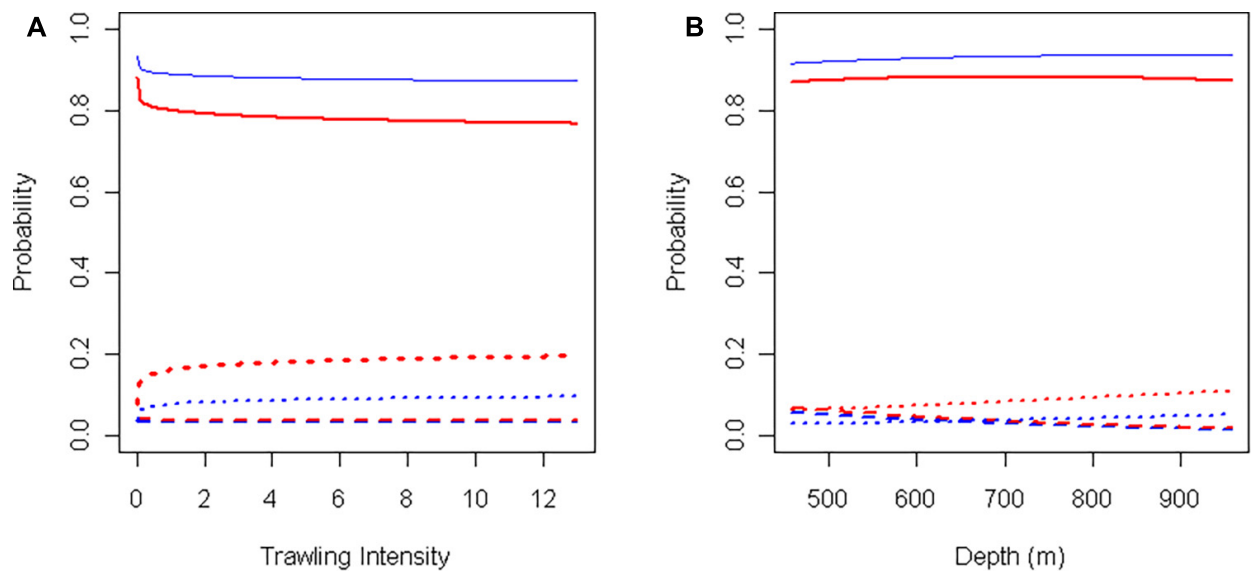

FIGURE 6 | Model predictions of the probability of intact (solid), tipped (dashed), or broken (dotted) Keratoisis grayi in Halibut Channel (blue) and Haddock Channel (red) in relation to $(\mathbf{A})$ trawl intensity (depth $=650 \mathrm{~m}$ ), and $\mathbf{( B )}$ depth (trawl intensity =0).

\section{Height}

Colony height increased significantly with bottom depth, a pattern previously reported for bubble gum coral, Paragorgia arborea, in the Northeast Channel off Nova Scotia (Watanabe et al., 2009). Thresher (2009) found slower radial growth rates in bamboo corals collected in deeper waters and at lower temperatures, suggesting much longer growth periods without disturbance for deeper, taller corals than shallower, faster growing colonies.

Our models predicted that the largest bamboo coral colonies occur on boulders in Halibut Channel and boulders and cobble in Haddock Channel (acknowledging a significant positive interaction between canyon and bottom type). We suspect that the larger surface area of boulders offers a more stable surface as colonies grow in size, thus allowing a colony to grow larger before tipping and overturning the stone (Tunnicliffe and Syvitski, 1983).

As with coral abundance patterns, size, and growth rates may link to a variety of environmental factors that likely vary with depth and differ between canyons. These factors include, but are not limited to, currents, strontium/calcium ratios, surface productivity, calcium carbonate, and organic content (Weinbauer et al., 2000; Thresher, 2009).

\section{Condition}

The majority of $K$. grayi observed in both Halibut and Haddock Channels were healthy (80\%) and fully living (78\%). Dead/partially dead colonies of $K$. grayi were more prevalent at 
shallower depths in Haddock Channel than Halibut Channel, and colonies in Haddock Channel were broken more often and generally less intact compared to those in Halibut Channel. Trawling could explain this difference. Although we attempted to account for trawl intensity in our models, we may have underestimated areas of past trawling if our survey path did not intersect the trawl-door furrow. We observed a total of 80 trawls marks in Haddock Channel, compared to only 12 in Halibut Channel, and the Haddock Channel survey site is relatively close to locations where $>100 \%$ of the area was trawled at least 1 year between 1980 and 2000 (Kulka and Pitcher, 2001). Therefore, in our survey areas, trawling pressure in Haddock Channel likely exceeded that in Halibut Channel and the poorer health of $K$. grayi in Haddock Channel may reflect fishing damage not captured with our methodologies. This interpretation would also explain the absence of significant differences in probability of tipped colonies between canyons. The physical force of a trawl would likely break or tip and break a colony, rather than tip a colony without breakage (Sainsbury et al., 1992; Krieger, 2001). Alternatively, many of the variables that likely differ between canyons and affect size and abundance (e.g., current velocity, sedimentation rates, and temperature), may also impact overall $K$. grayi condition and contribute to the canyon-related patterns.

Numerous mechanisms can tip and break colonies, sometimes overturning the attachment substrate (Tunnicliffe and Syvitski, 1983). For example, longlines or gillnets may hook corals (Krieger, 2001). Therefore, we cannot identify the direct mechanism responsible for the colonies that were tipped and/or broken in our video.

\section{Trawling Impacts}

Our results clearly illustrate the negative influence of trawling on the size, condition, and number of K. grayi off Newfoundland. However, K. grayi were also more likely to occur in trawled areas, perhaps because fishers target areas with high densities of fish, which could coincide with coral presence (Husebo et al., 2002; Costello et al., 2005; Stone, 2006). But corals that persist in trawled areas are more likely to exhibit damage, breakage, smaller size, and reduced abundance. These findings confirm other studies on trawling effects on vulnerable epifauna. For example, Yoklavich et al. (2018) considered only half of the bamboo corals healthy in a heavily trawled area, and observed bamboo corals sheared off at the base, and linear swaths of broken and/or dead colonies. Freese (2001) found an immediate $16 \%$ reduction in sponge density post trawling, a $21 \%$ reduction 11 months post trawling, and damaged to almost half of the sponges (46.8\%) that remained in three trawl paths. Trawled seamounts exhibited significantly reduced cover of Solenosmilia thickets compared to seamounts that were never trawled, with significantly higher density of large gorgonians and black corals with broken stems on seamounts with active trawling (Althaus et al., 2009). One study in the Gulf of Alaska estimated that $27 \%$ of corals in a trawl net path were detached and 50-90\% of these corals were missing polyps (Krieger, 2001). Damaged corals may be more susceptible to predation (Malecha and Stone, 2009), infection and disease and, ultimately, mortality (Krieger, 2001), with reduced reproductive (Henry et al., 2003; Malecha and Stone, 2009), and feeding abilities (Krieger, 2001), and slower growth rates (Meesters et al., 1994). For example, Tritonia diomedea actively fed on sea whips lying on the seafloor after simulated trawl disturbance (Malecha and Stone, 2009).

Our predictive models clearly corroborate previous research illustrating the significant damage caused by the first pass of a trawl. In each model, we found the largest incremental effect of trawling with the smallest number of trawls (illustrated by initial slopes in Figures 3-6). On the continental shelf of Australia, a single pass of a trawl removed $90 \%$ of the large epibenthic organisms in the trawl path (Sainsbury et al., 1992). A single trawl pass in the Gulf of Alaska significantly removed or damaged emergent epifauna (Freese et al., 1999). Van Dolah et al. (1987) found significantly reduced barrel sponge abundances and octocorals and stony corals broken at the base after only a single trawl pass.

Our findings use observations collected with an ROV and quantitative methods to add to the growing research demonstrating clear impacts of trawling on deep-sea ecosystems (e.g., Watling and Norse, 1998; Freese, 2001; Althaus et al., 2009; Norse et al., 2012; Clark et al., 2016; Yoklavich et al., 2018). Slow-growing and long-lived octocorals, such as K. grayi will require considerable time to recover from disturbances (Roberts et al., 2009), if even possible, and other taxa in the deep sea may depend on octocorals (Buhl-Mortensen et al., 2010). Collectively, these findings raise significant concerns regarding trawling impacts and sustainability of deep-sea ecosystems. Therefore, we believe protection of corals, associated taxa, and their ecosystems requires closing large areas of the seafloor to destructive fishing gear. In areas that remain open to trawling (and other fishing practices), ensuring appropriate fisheries management in an ecosystem context requires accountability and transparency (Weaver et al., 2011).

In conclusion, we used quantitative methods to clearly illustrate the negative influence of trawling on $K$. grayi counts, size, and status. Our findings also suggest fishers may preferentially, though unintentionally, target areas with $K$. grayi, underscoring the urgency of this conservation threat. Therefore, our research adds to growing evidence for the need to protect large seabed areas from bottom trawling. Such protected areas will help to reduce the overall footprint of fishing and initiate recovery efforts for deep-sea corals and associated marine fauna.

\section{DATA AVAILABILITY}

The datasets generated for this study can be found in the author's GitLab site: https://gitlab.com/krista.baker/keratoisis.

\section{AUTHOR CONTRIBUTIONS}

$\mathrm{KB}, \mathrm{PS}, \mathrm{RH}, \mathrm{EE}, \mathrm{VW}$, and KG contributed to the concept and initial study design. KB and VW performed the video analysis. KB 
and DF performed the statistical analyses and interpretation. $\mathrm{KB}$ wrote the first draft of the manuscript. All authors contributed to the manuscript revisions. KB, PS, EE, VW, and KG have read and approved the submitted version of the manuscript. RH approved a previous, but very similar, version of the manuscript.

\section{FUNDING}

This research was supported by the Natural Sciences and Engineering Research Council of Canada (NSERC) Postgraduate Scholarship to KB, NSERC Ship Time Grant to A. Mercier

\section{REFERENCES}

Althaus, F., Williams, A., Schlacher, T. A., Kloser, R. J., Green, M. A., Barker, B. A., et al. (2009). Impacts of bottom trawling on deep-coral ecosystems of seamounts are long-lasting. Mar. Ecol. Prog. Ser. 397, 279-294. doi: 10.3354/ meps08248

Appeltans, W., Bouchet, P., Boxshell, G. A., De Broyer, C., de Voodg, N. J., Gordon, D. P., et al. (2012). World Register of Marine Species. Available at: http://www.marinespecies.org. (accessed October 6, 2012)

Baillon, S., Hamel, J.-F., Wareham, V. E., and Mercier, A. (2012). Deep coldwater corals as nurseries for fish larvae. Front. Ecol. Environ. 10, 351-356. doi: $10.1890 / 120022$

Baker, K. D., Wareham, V., Snelgrove, P. V. R., Haedrich, R. L., Fifield, D. A., Edinger, E. N., et al. (2012a). Distributional patterns of deep-sea coral assemblages in three submarine canyons off Newfoundland, Canada. Mar. Ecol. Prog. Ser. 445, 235-249. doi: 10.3354/meps09448

Baker, K. D., Haedrich, R. L., Snelgrove, P., Wareham, V., Edinger, E. N., and Gilkinson, K. (2012b). Small-scale patterns of deep-sea fish distributions and assemblages of the Grand Banks, Newfoundland continental slope. Deep Sea Res. A Oceanogr. Res. Papers 65, 171-188. doi: 10.1016/j.dsr.2012. 03.012

Benjamin, R. (2007). ClassAct Mapper. Dartmouth, NS: Fisheries and Oceans Canada.

Bryan, T. L., and Metaxas, A. (2006). Distribution of deep-water corals along the North American continental margins: relationships with environmental factors. Deep Sea Res. I Oceanogr. Res. Papers 53, 1865-1879. doi: 10.1016/j.dsr.2006.09. 006

Buhl-Mortensen, L., Vanreusel, A., Gooday, A. J., Levin, L. A., Priede, I. G., Buhl-Mortensen, P., et al. (2010). Biological structures as a source of habitat heterogeneity and biodiversity on the deep ocean margins. Mar. Ecol. 31, 21-50. doi: $10.1111 / j .1439-0485.2010 .00359 . x$

Clark, M. R., Althaus, F., Schlacher, T. A., Williams, A., Bowden, D. A., and Rowden, A. A. (2016). The impacts of deep-sea fisheries on benthic communities: a review. ICES J. Mar. Sci. 73(Suppl. 1), i51-i69. doi: 10.1371/ journal.pone. 0022588

Costello, M. J., McCrea, M., Freiwald, A., Lundalv, T., Jonsson, L., Bett, B. J., et al. (2005). "Role of cold-water Lophelia pertusa coral reefs as fish habitat in the NE Atlantic," in Cold-Water Corals and Ecosystems, eds A. Freiwald and J. M. Roberts (Berlin: Springer-Verlag), 771-805. doi: 10.1007/3-540-27 673-4_41

CSSF (2010). Canadian Scientific Submersible Facility. British Columbia, BC: CSSF.

Dayton, P. K., Thrush, S. F., Agardy, M. T., and Hofman, R. J. (1995). Environmental effects of marine fishing. Aquat. Conserv. Mar. Freshwater Ecosyst. 5, 205-232. doi: 10.1002/aqc.3270050305

Deichmann, E. (1936). The Alcyonaria of the western part of the Atlantic Ocean. Memoires of the Museum of Comparative Zoology, Vol. 53. Cambridge, MA: Harvard College, 1-317.

Edinger, E. N., Baker, K. D., Devillers, R., and Wareham, V. (2007). Coldwater Corals Off Newfoundland and Labrador: Distribution and Fisheries Impacts. Toronto,ON: World Wildlife Fund, 41.

ESRI (2008). ArcGIS 9.3. Redlands, CA: Environmental Systems Research Institute. et al., NSERC Discovery Grants to PS and EE, and Fisheries and Oceans Canada International Governance Strategy grant to $\mathrm{KG}$.

\section{ACKNOWLEDGMENTS}

We sincerely thank the crews of CCGS Hudson and ROPOS. We also thank Brenda Oake and Calan Fisher for their help with the video analysis, and Robert Benjamin for his explanations of ClassAct Mapper. We also thank Monty Priede, Suzanne Dufour, and Annie Mercier for their comments on an earlier draft of the manuscript.

Fossa, J. H., Mortensen, P. B., and Furevik, D. M. (2002). The deep-water coral Lophelia pertusa in Norwegian waters: distribution and fishery impacts. Hydrobiologia 471, 1-12.

Freese, J. L. (2001). Trawl-induced damage to sponges observed from a research submersible. Mar. Fish. Rev. 63, 7-13.

Freese, L., Auster, P. J., Heifetz, J., and Wing, B. L. (1999). Effects of trawling on seafloor habitat and associated invertebrate taxa in the Gulf of Alaska. Mar. Ecol. Prog. Ser. 182, 119-126. doi: 10.3354/meps182119

Gass, S. (2003). Conservation of Deep-Sea Corals in Atlantic Canada. Toronto, ON: World Wildlife Fun - Canada, 54.

Henry, L. A., Kenchington, E. L. R., and Silvaggio, A. (2003). Effects of mechanical experimental disturbance on aspects of colony responses, reproduction, and regeneration in the cold-water octocoral Gersemia rubiformis. Can. J. Zool. Rev. Canadienne De Zool. 81, 1691-1701. doi: 10.1139/z03-161

Husebo, A., Nottestad, L., Fossa, J. H., Furevik, D. M., and Jorgensen, S. B. (2002). Distribution and abundance of fish in deep-sea coral habitats. Hydrobiologia 471, 91-99.

Jackman, S., Tahk, A., Zeileis, A., Maimone, C., and Fearon, J. (2011). Package 'pscl'. Stanford CA: Standford University.

Koen-Alonso, M., Favaro, C., Ollerhead, N., Benoit, H., Bourdages, H., SainteMarie, B., et al. (2018). Analysis of the overlap between fishing effort and Significant Benthic Areas in Canada's Atlantic and Eastern Arctic marine waters. DFO Can. Sci. Advis. Sec. Res. Doc. 2018/015 xvii +270 .

Koenig, C. C., Shepard, A. N., Reed, J. K., Coleman, F. C., Brooke, S. D., Brusher, J., et al. (2005). Habitat and fish populations in the deep-sea Oculina coral ecosystem of the western Atlantic. Am. Fish. Soc. Symposium 41, 795-805.

Krieger, K. J. (2001). "Coral (Primnoa). impacted by fishing gear in the Gulf of Alaska," in Proceedings of the First International Symposium on Deep Sea Corals, eds J. H. M. Willison, J. Hall, and S. E. Gass (Halifax, NS: Ecology Action Centre), 156-165.

Kulka, D. W., and Pitcher, D. A. (2001). Spatial and temporal patterns in trawling activity in the Canadian and Pacific. ICES CM R 02, 1-55.

Malecha, P. W., and Stone, R. P. (2009). Response of the sea whip Halipteris willemoesi to simulated trawl disturbance and its vulnerability to subsequent predation. Mar. Ecol. Prog. Ser. 388, 197-206. doi: 10.3354/meps08145

Meesters, E. H., Noordeloos, M., and Bak, R. P. M. (1994). Damage and regeneration - links to growth in the reef-building coral Montastrea annularis. Mar. Ecol. Prog. Ser. 112, 119-128. doi: 10.3354/meps112119

Mortensen, P. B., and Buhl-Mortensen, L. (2005). "Deep-water corals and their habitats in The Gully, a submarine canyon off Atlantic Canada," in ColdWater Corals and Ecosystems, eds A. Freiwald and J. M. Roberts (Berlin: Springer-Verlag), 247-277. doi: 10.1007/3-540-27673-4_12

Mortensen, P. B., Buhl-Mortensen, L., and Gordon, D. C. (2006). "Distribution of deep-water corals in Atlantic Canada," in Proceedings of the 10th International Coral Reef Symposium, (Okinawa), 1832-1848.

Murillo, F. J., Durán Munoz, P., Altuna, A., and Serrano, A. (2010). Distribution of deep-water corals of the Flemish Cap, Flemish Pass, and the Grand Banks of Newfoundland (Northwest Atlantic Ocean): interaction with fishing activities. ICES J. Mar. Science 68, 319-332. doi: 10.1093/icesjms/fsq071

Norse, E. A., Brooke, S., Cheung, W. W. L., Clark, M. R., Ekeland, L., Froese, R., et al. (2012). Sustainability of deep-sea fisheries. Mar. Policy 36, 307-320. 
RDevCoreTeam. (2012). R: A Language and Environment for Statistical Computing. Vienna: R Foundation for Statistical Computing.

Roberts, J. M., Wheeler, A. J., Freiwald, A., and Cairns, S. (2009). Cold-water Corals: The Biology and Geology of Deep-sea Coral Habitats. New York, NY: Cambridge University Press, 334 .

Roberts, S., and Hirshfield, M. (2004). Deep-sea corals: out of sight, but no longer out of mind. Front. Ecol. Environ. 2, 123-130. doi: 10.1890/1540-9295(2004) 002\%5B0123:dcoosb\%5D2.0.co;2

Sainsbury, K. J., Campbell, D. E., and Whitelaw, A. W. (1992). "Effects of trawling on the marine habitat on the North West shelf of Australia and implications for sustainable fisheries management," in Sustainable Fisheries through Sustaining Fish Habitat. Australian Society for Fish Biology Workshop, ed. D. A. Hancock (Canberra: Australian Government Publishing Service), 137-145.

Sherwood, O. A., and Edinger, E. N. (2009). Ages and growth rates of some deepsea gorgonian and antipatharian corals of Newfoundland and Labrador. Can. J. Fish. Aquat. Sci. 66, 142-152. doi: 10.1139/f08-195

Stone, R. (2006). Coral habitat in the Aleutian Islands of Alaska: depth distribution, fine-scale species associations, and fisheries interactions. Coral Reefs 25, 229238. doi: 10.1007/s00338-006-0091-z

Thresher, R. E. (2009). Environmental and compositional correlates of growth rate in deep-water bamboo corals (Gorgonacea; Isididae). Mar. Ecol. Prog. Ser. 397, 187-196. doi: 10.3354/meps08245

Thrush, S. F., Hewitt, J. E., Funnell, G. A., Cummings, V. J., Ellis, J., Schultz, D., et al. (2001). Fishing disturbance and marine biodiversity: the role of habitat structure in simple soft-sediment systems. Mar. Ecol. Prog. Ser. 223, 277-286. doi: 10.3354/meps223277

Tunnicliffe, V., and Syvitski, J. P. M. (1983). Corals move boulders - an unusual mechanism of sediment transport. Limnol. Oceanogr. 28, 564-568. doi: $10.4319 /$ lo.1983.28.3.0564

van der Land, J. (1994). UNESCO-IOC Register of Marine Organisms, a common base for biodiversity inventories. Leiden: NNM.

Van Dolah, R. F., Wendt, P. H., and Nicholson, N. (1987). Effects of a research trawl on a hard-bottom assemblage of sponges and corals. Fish. Res. 5, 39-54. doi: 10.1016/0165-7836(87)90014-2

Wareham, V. E., and Edinger, E. N. (2007). Distribution of deep-sea corals in the Newfoundland and Labrador region, Northwest Atlantic Ocean. Bull. Mar. Sci. 81, 289-313. doi: 10.1371/journal.pone.0111519
Watanabe, S., Metaxas, A., Sameoto, J., and Lawton, P. (2009). Patterns in abundance and size of two deep-water gorgonian octocorals, in relation to depth and substrate features off Nova Scotia. Deep Sea Res. I Oceanogr. Res. Papers 56, 2235-2248. doi: 10.1016/j.dsr.2009.09.003

Watling, L., and Norse, E. A. (1998). Disturbance of the seabed by mobile fishing gear: A comparison to forest clearcutting. Conserv. Biol. 12, 1180-1197. doi: 10.1046/j.1523-1739.1998.0120061180.x

Weaver, P. P. E., Benn, A., Arana, P., Ardron, J., Bailey, D. M., Baker, K. D., et al. (2011). The impact of deep-sea fisheries and implementation of the UNGA Resolutions 61/105 and 64/72. Report of an international scientific workshop. Southampton: National Oceanography Centre, 45.

Weinbauer, M. G., Brandstatter, F., and Velimirov, B. (2000). On the potential use of magnesium and strontium concentrations as ecological indicators in the calcite skeleton of the red coral (Corallium rubrum). Mar. Biol. 137, 801-809. doi: 10.1007/s002270000432

Yesson, C., Taylor, M. L., Tittensor, D. P., Davies, A. J., Guinotte, J., Baco, A., et al. (2012). Global habitat suitability of cold-water octocorals. J. Biogeogr. 39, 1278-1292. doi: 10.1111/j.1365-2699.2011.02681.x

Yoklavich, M. M., Laidig, T. E., Graiff, K., Clarke, M. E., and Whitmire, C. E. (2018). Incidence of disturbance and damage to deep-sea corals and sponges in areas of high trawl bycatch near the California and Oregon border. Deep sea Res. II 150, 156-163. doi: 10.1016/j.dsr2.2017.08.005

Zuur, A. F., Ieno, E. N., Walker, N. J., Saveliev, A. A., and Smith, G. M. (2009). Mixed Effects Models and Extensions in Ecology with R. New York, NY: Springer, 574.

Conflict of Interest Statement: The authors declare that the research was conducted in the absence of any commercial or financial relationships that could be construed as a potential conflict of interest.

Copyright (c) 2019 Baker, Snelgrove, Fifield, Edinger, Wareham, Haedrich and Gilkinson. This is an open-access article distributed under the terms of the Creative Commons Attribution License (CC BY). The use, distribution or reproduction in other forums is permitted, provided the original author(s) and the copyright owner(s) are credited and that the original publication in this journal is cited, in accordance with accepted academic practice. No use, distribution or reproduction is permitted which does not comply with these terms. 